A pidologie, 1984, 15 (1), 23-32.

\title{
THE FUNCTION OF THE ANTENNA CLEANER OF THE HONEYBEE (APIS MELLIFICA)
}

\author{
Klaus SCHÖNITZER and Maximilian RENNER \\ Zoologisches Institut der Universität München, Luisensir. 14, D-8000 München 2, \\ Fed. Rep. of Germany
}

\begin{abstract}
SUMMARY
This paper describes the antenna cleaning activity of the worker honeybee (Apis mellifica) in detail. Our results are documented by a series of photographs of a grooming honeybee taken simultaneously from front, from the side and from above. The flagellum is cleaned by being inserted into the tibio-tarsal antenna cleaner (strigilis) of the ipsilateral fore leg. During the cleaning stroke an angle of about $100^{\circ}$ is maintained between the tibia and the tarsus. During the cleaning procedure the antenna is almost completely enclosed by the strigilis; its anterior part is brushed by the strigular comb, its posterior side cleaned by the posterior velum of the strigular spur.
\end{abstract}

\section{INTRODUCTION}

Bees, like other hymenoptera, have a special structure on their forelegs to clean their antennae with. The morphology of this antenna cleaner (strigilis *) has been described in detail for Apis mellifica as well as for a number of different species of bees (SCHÖNITZER and RENNER, 1980). The antenna cleaner of the honeybee (fig. 1) is composed of a deep notch on the inner (ventral) surface of the proximal end of the basitarsus and a large spur, which is movable, inserted at the inner angle of the distal end of the tibia. The notch bears on its posterior end a semicircular comb of fine, closely set hairs. The spur consists of a trunk with an apex and two lobes (vela), the larger of which is directed posteriorly, the smaller (spatulate accessory lobe, SNODGRASs, 1956) anteriorly.

*In accordance to Michener (1944) we use «strigilis» and «antenna cleaner» as synonyms. 


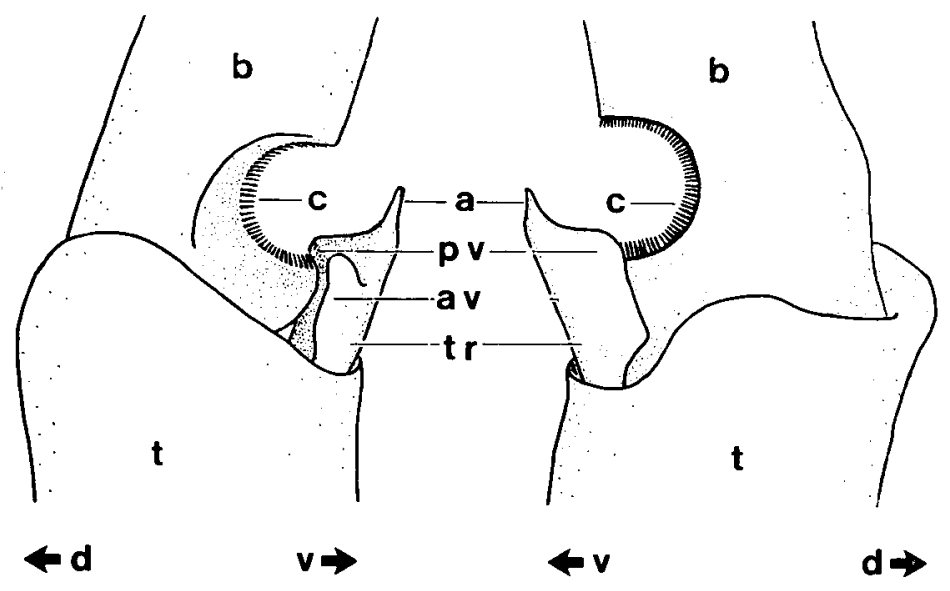

FIG. 1. - Antenna cleaner (strigilis) of a honeybee, from a left foreleg.

Left as seen from anterior, right from posterior; top : distal; a : apex; av : anterior velum ; b : basitarsus ; c : comb; $\mathrm{d}$ : dorsal; pv : posterior velum; $\mathrm{t}:$ tibia ; tr : trunk; $\mathrm{v}$ : ventral.

Antenna grooming in Apis mellifica has previously been described by BeEcken (1934), SNODGrass (1956), and JANDER (1976), as far as observable with the naked eye. The aim of this study is to document the motion in detail with a series of photographs, to see how the antenna is inserted into the strigilis during the stroke, and to examine the functions of the different parts of the antenna cleaner.
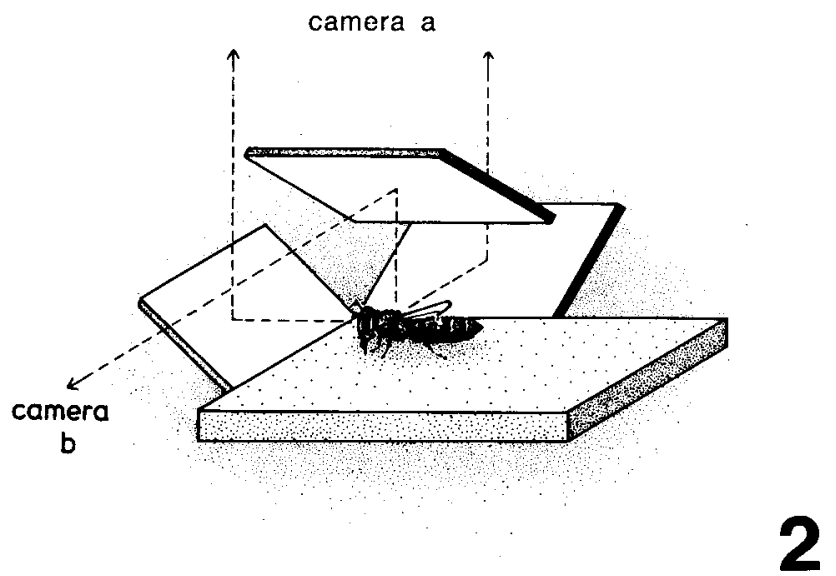

FIG. 2. - Arrangement of mirrors to take photographs of a bee from top (camera b), from the side, and from front (camera a), simultaneously with two cameras. 


\section{METHODS}

\section{Photographic analysis}

To reconstruct the motion of antenna cleaning, we took photographs of its different phases. Each phase was repeatedly documented by a set of exposures showing the bee simultaneously from the side, the front, and from above. To make this possible we used two cameras and a set of surface coated mirrors (fig. 2). The cameras were synchronized with the help of a flashlight. To reduce perspective distortion we used tele-photo lenses. We raised the frequency of antenna cleaning by applying small amounts of dust (plaster of Paris, flour, pollen, etc.) or glue onto the antennac. During the whole procedure the bee was fixed on its notum with wax-colophony, which is a mixture of beeswax and resin.

\section{Calculation of the angle between tibia and basitarsus}

We measured the virtual inclination of tibia and basitarsus versus the horizontal plane by using photographs taken from the side and the front. The actual angle between tibia and basitarsus could then be calculated with the help of a trigonometric formula :

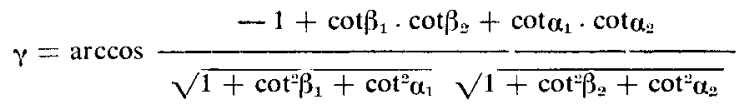

with $\alpha_{1}$ and $\alpha_{2}$ representing the inclination of the tibia, and $\beta_{1}$ and $\beta_{2}$ the inclination of the basitarsus in the front and side view respectively. The photographic analysis was based on series of pictures taken from five worker honeybees.

\section{Position of the flagellum in the strigilis}

To determine their exact position in the strigilis, we inserted flagella into the strigilis of amputated legs taken from fresh bees. This was done with the help of a stereo microscope. The positions of tibiae and basitarsi were mechanically fixed at various angles to each other. The preparations were then dried and examined light-microscopically or using a scanning electron microscope.

\section{Scraping tests}

To find out which parts of the cleaning apparatus scrape the dirt off the antenna we applied some graphite powder suspended in sucrose solution onto the flagellum of a freely moving bee. To prohibit cleaning of the strigilis with the ipsilateral middle leg, which generally follows antenna cleaning, the leg had been amputated before. Immediately following one scraping stroke the fore leg was amputated and prepared for conventional scanning electron microscopy. Seventeen worker honeybees were used for these tests.

\section{RESULTS}

\section{Description of the antenna cleaning procedure}

Honeybees (Apis mellifica) invariably clean their antennae with the ipsilateral foreleg. They hardly ever clean both antennae at the same time even if both are soiled. In this case the bee cleans first one, then the other antenna. Almost invariably honeybees clean their antenna with only one stroke, then turn 

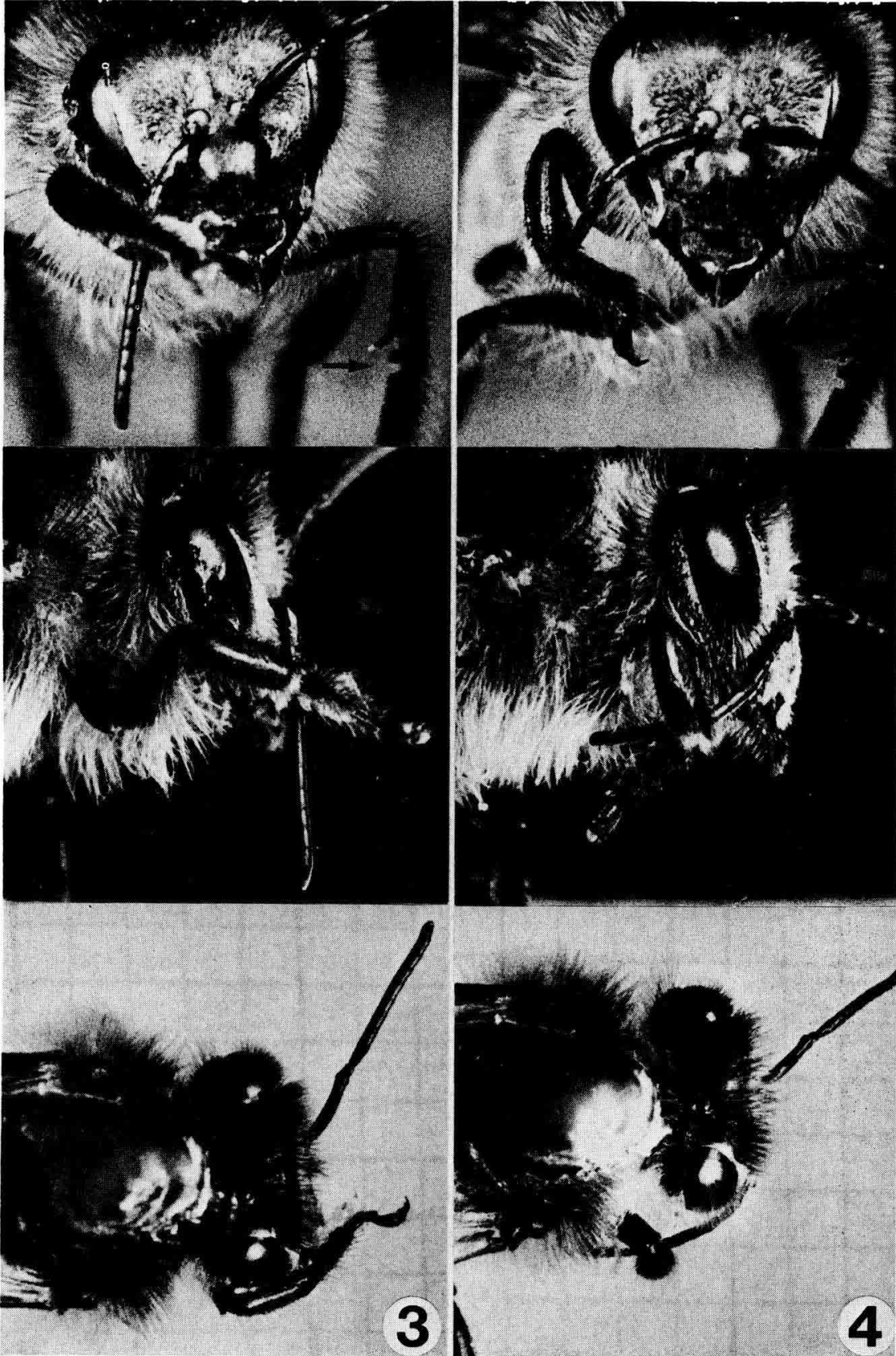

FIg. 3, 4. - Honeybee cleaning an antenna. Each set of photographs shows the bee in the same moment from front (top), from the side (middle), and from above (below). 3. The bee puts the leg over the antenna, the tibio-tarsal joint is still extended, the antenna is not yet enclosed in the strigilis. On the opposite leg the strigilis is visible (arrow). 4. The basitarsus is bent against the tibia, the flagellum is enclosed in the strigilis. Half the flagellum is already cleaned. 


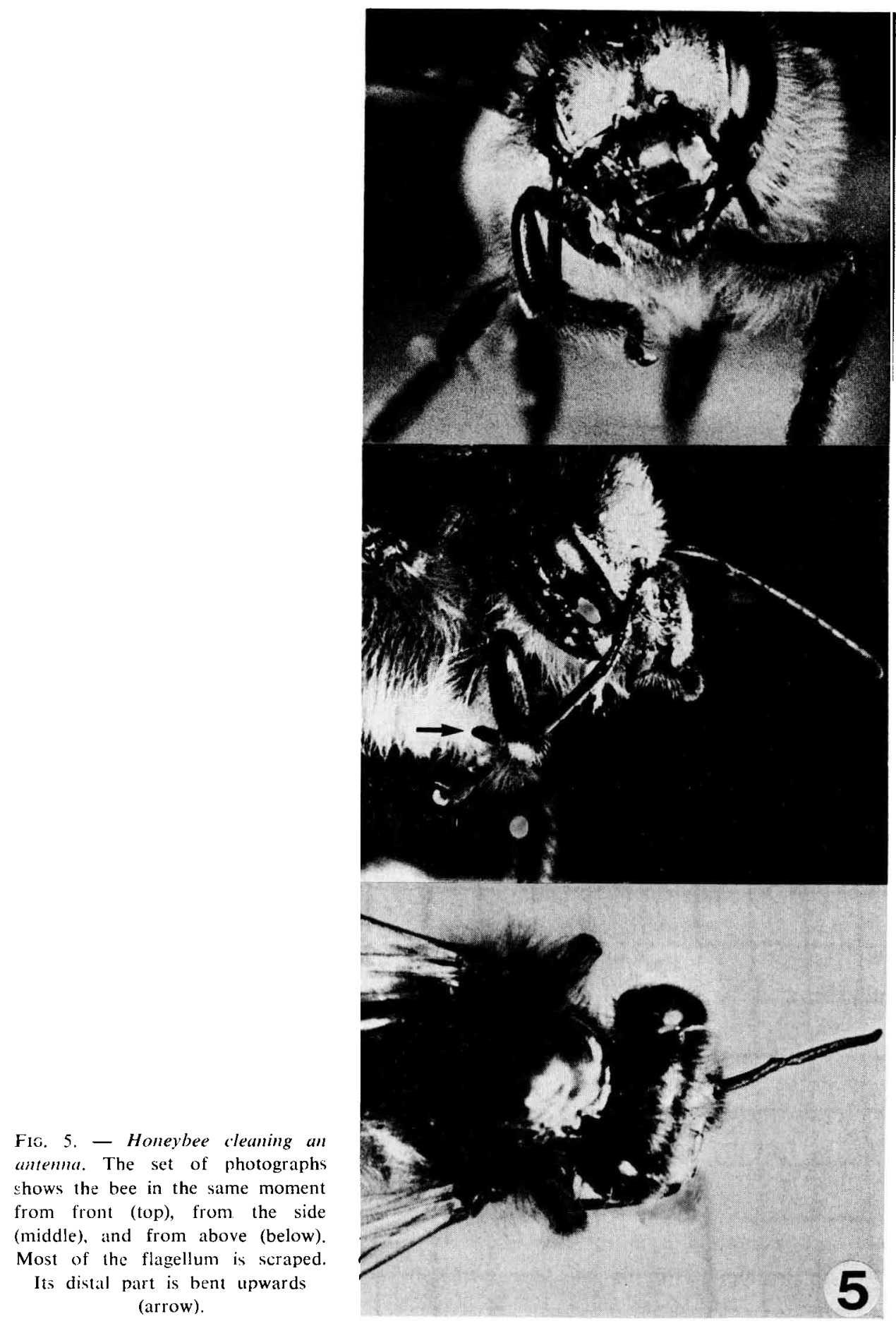


to other behaviour, unless the antenna is contaminated with glue or similar adhesives for experimental purpose. Repetitive antenna grooming as mentioned by BEECKEN (1934) is hardly ever observed under natural conditions (cf. JANDI:R, 1976).

Immediately before the cleaning stroke the antenna is lowered, and the first leg is lifted above the antenna. Often, though not always, the head is turned toward the cleaning leg, but it is not lowered. The antenna is put into the strigilis, approximately in the region of the pedicel or the first flagellar segment (fig. 3). By bending the basitarsus against the tibia (fig. 4) the antenna cleaner is closed around the flagellum (see below). The subsequent scraping movement is directed back- and downwards, i.e. distad with regard to the antenna. The strigilis thus only cleans the flagellum, not its base.

While performing the cleaning stroke, the bee presses the scape of the antenna against its head (gena). Sometimes the stroke is reinforced by a counterrotation of the head. The distal part of the flagellum, which has not yet passed the strigilis is bent upwards. This is especially evident toward the end of the stroke (fig. 5).

\section{Structure and function}

In preparations of amputated legs the flagellum is differently encompassed by the different parts of the strigilis depending on the angle between tibia and basitarsus. This angle, however, was found to be remarkably constant in our photographs of antenna cleaning bees (figs. 3-5). It varied from 97 to $107^{\circ}$ (average $101^{\prime \prime} \pm 3.08^{\circ} \mathrm{SD}, \mathrm{n}=11$ ), where the exactncss of measuring the photographs was estimated to be about $\pm 5^{\prime \prime}$. Furthermore the angle was found to b: maintained throughout the cleaning stroke. A preparation of an amputated leg with this angle between tibia and basitarsus is shown in figure 6 . Thus this figure can be said to represent the actual anatomical configuration of the strigilis during the cleaning stroke. The flagellum is almost completely encircled by the spur and the notch. Thus one side of the flagellum can be scraped by the posterior rim of the hind velum (fig. 1, pv), and the other side by the comb (fig. 1, c). Moreover the spur touches the flagellar surface with its anterior velum (lig. 1, av), but not with its apex. Further evidence that comb and posterior velum are the scraping parts of the cleaning apparatus could be obtained by the "scraping tests ». After cleaning the antenna dirt was mostly located on the outside of the posterior velum and on the outer surface of the comb (fig. 7). In addition to that the distal part of the anterior velum showed accumulations of dust in some cases. 


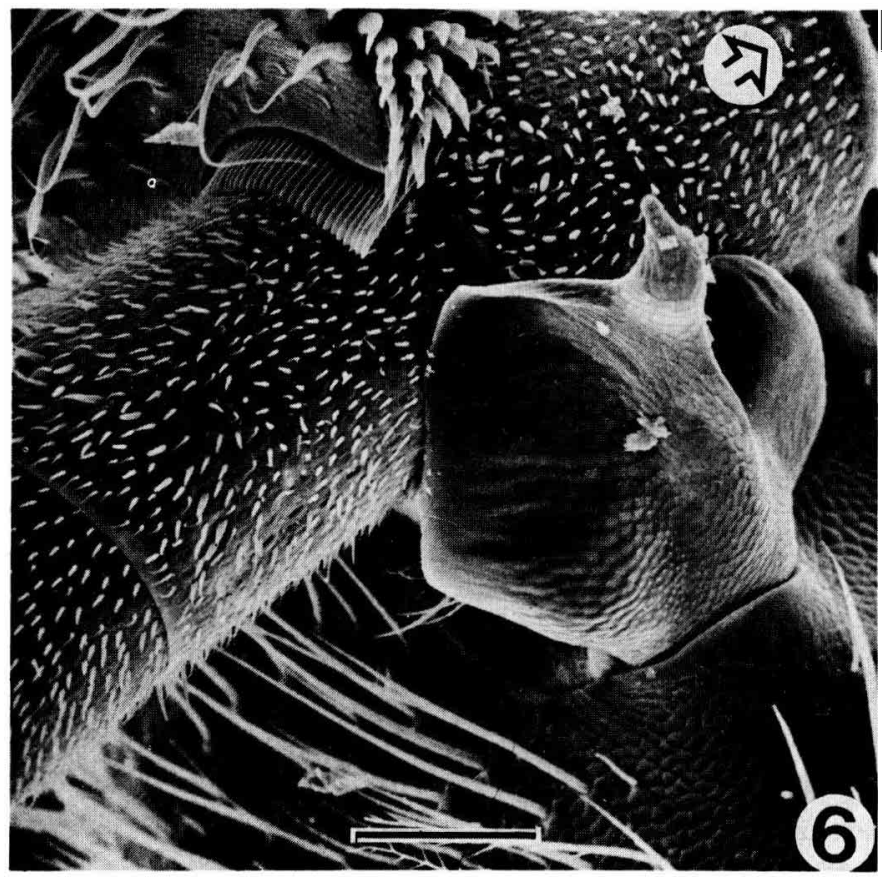

Fici. 6. - Approximate position of the flagellum in the strigilis, as during the cleanimg stroke. Note that the flagellum is almost completely enclosed in the antenna cleaner. Orientation : right leg seen from ventral, top : distal, right : anterior. Arrow indicates the direction of the movement of the flagellum through the strigilis. Magnification bar $0.1 \mathrm{~mm}$.

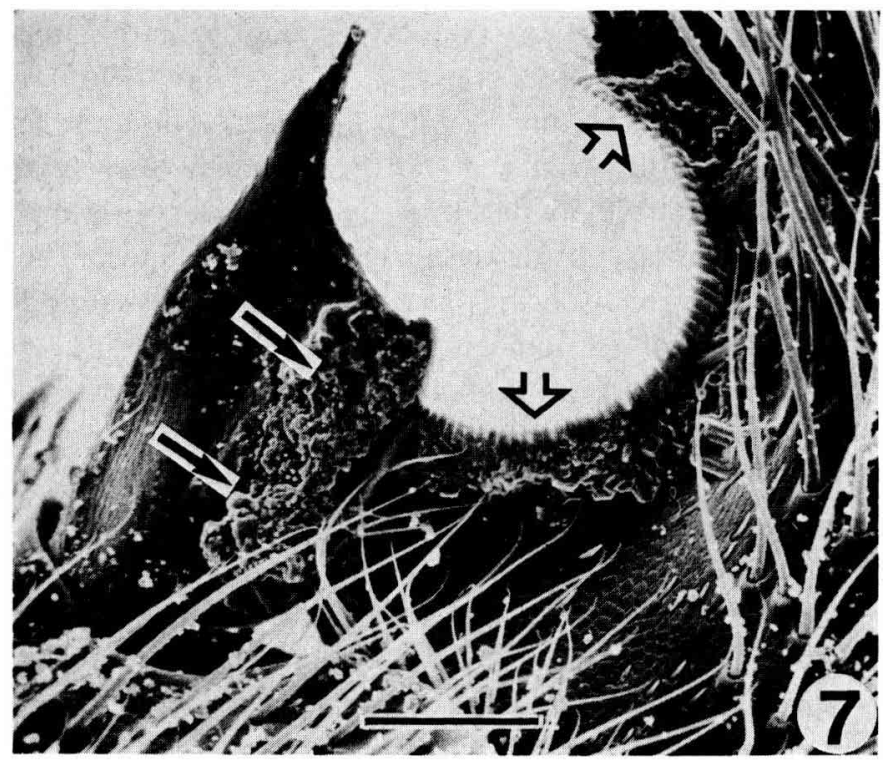

Fic. 7. - Antenta claner of a honeybee with the dirt scraped off from an antenna.

Note the accumulation of dirt on the posterior velum (slender arrows) and at the outside of the comb (open arrows). Orientation : Left leg seen from posterior, top : distal, left : ventral. Magnification bar $0.1 \mathrm{~mm}$. 
The flagellum is kept in the strigilis very tightly. This can be concluded from those preparations with an angle of $105^{\circ}$. A certain amount of pressure was necessary to obtain this angle between tibia and basitarsus. Without external power or fixation the leg opens elastically to about $115^{\circ}$.

\section{DISCUSSION}

The results presented here show that during the cleaning stroke the flagellum is almost completely surrounded by scraping structures in the strigilis, in which it is kept very tightly. This is contradictory to the assumptions of Gennerich (1922), who denied the possibility that the antenna can be enclosed by the strigilis.

Since the morphology of the strigilis of the queen and drone is quite similar to that of the worker bee (SchönItZer and RENNER, 1980) the function is probably identical.

The spur cannot be moved actively by separate muscles (SNODGiRASS, 1942; MARKL, 1966), but is inserted movably in the same plane as the tibio-tarsal joint. It can be bent outwards until its base touches the medio-distal edge of the tibia. During the grooming stroke the flagellum is pressed into the notch by the trunk of the spur, bending the tibio-tarsal joint with the tibial muscle 68 (depressor of the fore tarsus, SNodjrass, 1942; MarkL, 1966). The function of the apex and the anterior velum is not quite clear. The apex probably helps the flagellum to fit into the strigilis at the beginning of the stroke. The distal part of the anterior velum could perform some secondary wiping, since it also touches the flagellum during the stroke. Or else it could support the trunk of the spur as the flagellum is pressed against the comb. The lower bees do not possess an anterior velum, and only a number of Apidae do (Apis, Euslossa, Bombus, not Melipona; SchönITZler and RENNER, 1980). It is thus a very derived taxonomic character within the bees, which does not seem to be essential for antenna cleaning, but may help to increase its effectiveness. Remarkably there are two quite different structures to remove contaminations; $a$. the comb which consists of a row of fine and closely set hairs, and b. the posterior velum, which is a membraneous lobe. HLaVAC (1975) pointed out that generally the grooming mechanism in insects is a scraping with angled bristles or setae. Scraping with a membraneous lobe, as described here, seems to be quite unusual. The comb cleans the anterior part of the flagellum, which bears most of the antennal sensilla, and which thus needs a more intensive grooming than the posterior side of the flagellum with its clearly fewer sensilla (Essien and Kaissionsi, 1976). The latter is cleaned by the posterior velum. 
The very high effectiveness of the strigilis in Apis is demonstrated by the fact, that a honeybee hardly ever scrapes its antenna twice. Other species of bees (predominantly Colletidae, Halictidae, and Andrenidae JANDER, 1976), however, tend to clean their antennae with two strokes. This leads us to the assumption that the antenna cleaners of these bees have more ancestral morphology, as described for Colletes succinctus, Halictus sexcinctus, and Andrena ovulata (SCHÖNitzer and RENNER, 1980), which seems to be less effective than the strigilis of Apis.

Received for publication in November 1983.

Accepted for publication in January 1984.

\title{
ACKNOWLEDGEMENTS
}

We thank professor R. WETzSTEin, who enabled us to use the scanning electron microscope of the Anatomische Anstalt, München. Drs. Angelika and Alois Hofbauer improved the English of the manuscript.

\author{
RESUME \\ FONCTION DE L'APPAREIL DE NETTOYAGE DES ANTENNES \\ CHEZ, L'ABEILLE, APIS MELLIFICA
}

On décrit les mouvements par lesquels les ouvrières d'abeille (Apis mellifica) nettoient leurs antennes. Des séries de photos (fig. 3-5) montrent une abeille de face, de côté et de dos pendant qu'elle effectue Ie nettoyage. Pour ce faire, l'antenne est posée dans l'appareil de nettoyage de la patte antérieure du même côté, appareil qui est situé à l'articulation tibio-tarsale (fig. 1). Durant l'opération de nettoyage le tibia est courbé vers le basitarse avec un angle constant d'environ $100^{\circ}$. La figure 6 montre une préparation au microscope électronique à balayage sur laquelle un morceau de flagelle est inséré dans l'appareil de nettoyage grâce à cette flexion de l'articulation tibio-tarsale. L'antenne repose dans l'appareil de nettoyage à peu près de la même manière lors de l'opération de nettoyage. La flèche sur la figure 6 indique le sens dans lequel l'antenne passe à travers l'appareil de nettoyage. Le flagelle est alors presque totalement entouré par la brèche et l'éperon. La partie antérieure de l'antenne est nettoyée par le peigne, qui borde la brèche (fig. 1, c); tandis que la partie postérieure est nettoyée par le velum postérieur (lobe membraneux de l'éperon, fig. 1, pv). Ces données s'appuient sur les résultats des expériences au cours desquelles on a souillé volontairement l'antenne. La figure 7 montre un appareil de nettoyage avec des saletés prélevées sur l'antenne par le velum postérieur (flèche étroite) et par le peigne (flèche large).

\section{ZUSAMMENFASSUNG}

\section{FUNKTION DES ANTENNENPUTZAPPARATS BEI DER HONIGBIENE}

Der Bewegungsablauf des Antennenputzens bei Arbeiterinnen der Honigbiene (Apis mellifica) wurde beschrieben. Es wurden Fotoserien (Abb. 3-5) ausgewertet, die eine Biene beim Putzen gleich- 
zeitig von vorne, von der Seite und von oben zeigen. Zum Putzen wird die Antenne in den Putzapparat des gleichseitigen Vorderbeines gelegt, der sich am tibio-tarsalen Gelenk befindet (Abb. 1). Während des Putzvorganges ist die Tibia gegen den Basitarsus mit einem konstanten Winkel von ca. $100^{\circ}$ gebeugt. Abbildung 6 zeigt ein raster-elektronenmikroskopisches Präparat, bei dem ein Geißelstück bei dieser Beugung des tibio-tarsalen Gelenkes in den Putzapparat eingeklemmt ist. Etwa ebenso liegt die Antenne im Putzapparat während des Putzvorganges. Der Pfeil in Abbildung 6 zeigt die Richtung, in der die Antenne durch den Putzapparat gezogen wird. Die Geißel wird dabei fast vollständig durch die Scharte und den Sporn umschlossen. Die Vorderseite der Antenne wird durch den Kamm, der die Scharte begrenzt (Abb. 1, c), abgewischt, während die Hinterseite vom hinteren Velum (ein häutiger Lappen am Sporn; Abb. 1, pv) gereinigt wird. Dies wird durch die Ergebnisse von Beschmutzungsversuchen gestützt. Abbildung 7 zeigt einen Putzapparat mit von der Antenne abgestreiftem Schmutz am hinteren Velum (schlanke Pfeile) und am Kamm (offene Pfeile).

\section{BIBLIOGRAPHY}

Beecken W., 1934. - Über die Putz- und Säuberungshandlungen der Honigbiene (Apis mellifica). Arch. Bienenkd., 15, 213-275.

Esslen" J., Kaissling K.-E., 1976. - Zahl und Verteilung antennaler Sensillen bei der Honigbiene (Apis mellifera L.). Zoomorphologie, 83, 227-251.

Hlavac T.F., 1975. - Grooming systems of insects : structure, mechanics. Ann. entomol. Soc. Am., 68, 823-826.

JANDER R., 1976. - Grooming and pollen manipulation in bees (Apoidea) : the nature and evolution of movements involving the foreleg. Physiol. Entomol., 1, 179-194.

MARKL H., 1966. - Peripheres Nervensystem und Muskulatur im Thorax der Arbeiterin von Apis mellifica L., Formica polyctena Foerst. und Vespa vulgaris L. und der Grundplan der Innervierung des Insektenthorax. Zool. Jb. Anat., 83, 107-184.

Michener C.D., 1944. - Comparative External Morphology, Phylogeny, and a Classification of the Bees. Bull. am. Mus. Nat. Hist. 82, 151-326.

Schönitzer K., Renner M., 1980. - Morphologie der Antennenputzapparate bei Apoidea. Apidologie, 11, 113-130.

SNodgrass R.E., 1942. - The sceleto-muscular mechanisms of the honeybee. Smithson. Misc. Coll., 103 (2), 1-120.

Snodgrass R.E., 1956. - Anatomy of the Honeybee. New York. 